\title{
ST
}

Science \& Technology

PAPER - OPEN ACCESS

\section{Pemanfaatan Media Teka-Teki Silang (TTS) Untuk Meningkatkan Prestasi dan Kreativitas Siswa Pada Materi Klasifikasi Materi}

\author{
Author : Sri Wartika dkk., \\ DOI $\quad: 10.32734 /$ st.v2i1.349 \\ Electronic ISSN $\quad: 2654-7082$ \\ Print ISSN : :2654-7074
}

Volume 2 Issue 1 - 2018 TALENTA Conference Series: Science \& Technology (ST)

This work is licensed under a Creative Commons Attribution-NoDerivatives 4.0 International License.

Published under licence by TALENTA Publisher, Universitas Sumatera Utara

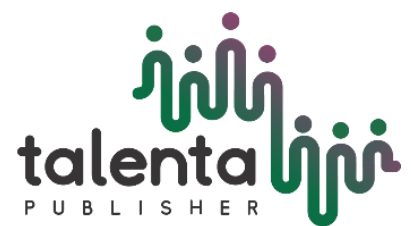




\title{
jibli talentaliois \\ TM Conference Series 02 (2019) \\ TALENTA Conference Series
}

Available online at https://talentaconfseries.usu.ac.id

\section{Pemanfaatan Media Teka-Teki Silang (TTS) Untuk Meningkatkan Prestasi dan Kreativitas Siswa Pada Materi Klasifikasi Materi}

\author{
Sri Wartika ${ }^{\mathrm{a}}$ dan Herbet C.B.Manalu ${ }^{\mathrm{b}}$ \\ ${ }^{a}$ Guru IPA SMP Negeri 3 Sunggal,Kabupaten Deli Serdang \\ ${ }^{a, b}$ Program Studi Pendidikan Kimia, Pascasarjana, Universitas Negeri Medan, Medan \\ sriwartika.pascakimia16@gmail.com
}

\begin{abstract}
Abstrak
Penelitian ini berupa penelitian tindakan yang bertujuan menerapkan penggunaan TTS sebagai media pembelajaran IPA untuk meningkatkan prestasi dan kreativitas siswa pada materi klasifikasi materi di kelas VII.Penelitian ini dilakukan dalam dua tahapan yang masing-masing tahapan terdiri dari satu kali pertemuan.Setiap tahapan terdiri dari siklus perencanaan (planning),tindakan (action),pengamatan (observation) dan refleksi(reflecting).Lokasi penelitian di laksanakan di SMP Negeri 3 Kecamatan Sunggal,Kabupaten Deli Serdang,sampel penelitian sebanyak 34 orang Siswa yang terdiri dari 17 Orang perempuan dan 17 orang laki-laki pada semester ganjil Tahun Ajaran 2016-2017.Teknik pengumpulan data dalam penelitian terdiri atas data kualitatif yang di dapat melalui pengamatan dan catatan di lapangan,serta data kuantitatif yang di dapat dari hasil belajar.Berdasarkan hasil penelitian disimpulkan bahwa penggunaan media TTS telah meningkatkan prestasi dan kreativitas Siswa pada materi klasifikasi materi di kelas VII.Berdasarkan hasil pengamatan pada tahap pertama di dapat ketuntasan belajar sebesar $60 \%$ dan pada tahap kedua didapat peningkatan hasil belajar sebesar $75 \%$,sedangkan kreativitas pada tahap pertama $60 \%$ dan pada tahap kedua meningkat $85 \%$.
\end{abstract}

Kata Kunci: TTS, prestasi, kreativitas, klasifikasi materi

\section{Pendahuluan}

Mata pelajaran kimia adalah mata pelajaran yang terintegrasi dengan mata pelajaran biologi dan fisika menjadi IPA terpadu di SMP.Salahsatu materi kimia yang diajarkan di SMP pada kelas VII adalah klasifikasi materi.Kesulitan yang biasanya dialami siswa ketika mempelajari klasifikasi materi adalah sulitnya mengingat nama nama unsur yang jarang mereka dengar ketika SD,karenanya perlu suatu pembelajaran bermakna yang dapat membantu siswa untuk mengatasi kesulitan belajar tersebut.Salah satunya menggunakan mediaTTS pada pembelajaran. Pemanfaatan media pembelajaran akan membantu guru mencapai tujuan pada proses belajar mengajar di kelas. Penggunaan media pembelajaran yang tepat dapat mempengaruhi aktivitas, minat dan motivasi belajar siswa yang akan mempengaruhi hasil pembelajarannya,berdasarkan tujuan pembelajaran dan karakteristik materi klasifikasi materi di kelas VII,siswa diharuskan mengingat nama-nama unsur kimia,materi kimia berupa hafalan terkesan sukar dan sulit diingat,sehingga proses pembelajaran terasa membosankan,karenanya guru harus bijak memanfaatkan berbagai media yang tepat dalam proses pembelajaran agar siswa mudah mengingat dan proses pembelajarannya pun terasa asyik, seperti pemanfaatan media TTS.

Berdasarkan peneltian PTK Luluk dkk. [1] menyimpulkan "pembelajaran berbasis otak berbantuan media tekateki silang memberikan kesempatan kepada siswa untuk membangun sendiri pengetahuannya,siswa mampu secara bebas menggunakan pengetahuannya untuk menyelesaikan masalah - masalah yang belum pernah dihadapi, serta memiliki tanggung jawab yang lebih terhadap belajarnya seiring dengan peningkatan pengalaman dan pengetahuan mereka".Hasil ini diperkuat oleh penelitian Fathonah [2] "salah satu kelebihan penggunaan media TTS yaitu dalam proses belajar mengajar siswa menjadi lebih aktif dan kreatif dalam kegiatan pembelajaran karena dalam 
penggunaan media TTS, siswa berusaha terampil dalam membuat TTS. Selain itu, pada penggunaan media TTS pengerjaan soalnya dituntut teliti, maka media TTS lebih merangsang siswa berpikir kritis dan kreatif“".

Berdasarkan latar belakang, dibuat Rumusan masalah pada penelitian:1).apakah pembelajaran dengan menggunakan media TTS dapat meningkatkan prestasi belajar siswa pada materi klasifikasi materi? 2).bagaimana kreativitas belajar siswa pada materi klasifikasi materi dengan menggunakan media TTS ?

Tujuan umum dari penelitian yaitu memanfaatkan TTS untuk meningkatkan prestasi dan kreativitas siswa terhadap materi pembelajaran,sedangkan tujuan khusus penelitian adalah :1).menggunakan TTSuntuk meningkatkan prestasi belajar siswa pada pembelajaran klasifikasi materi.2).melaksanakan pembelajaran dengan menggunakan media TTS untuk meningkatkan kreativitas belajar siswa pada pembelajaran klasifikasi materi. Sebagai lanjutan dari tujuan penelitian ini,didapat manfaat penelitian:1).sebagai bahan masukkan untuk Guru dalam mengatasi masalahpembelajaran klasifikasi materi.2).sebagai bahan referensi bagi peneliti lain yang ingin mengembangkan media TTS dalam pembelajaran.

\section{Metode}

Rancangan Penelitian. Rancangan penelitian ini dilaksanakan dalam serangkaian siklus tindakanyang dapat dilihat pada "Gambar 1".

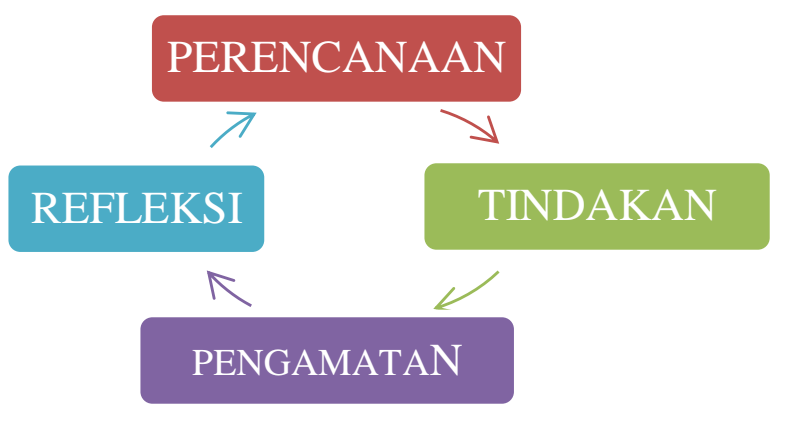

Gambar 1.Rancangan Penelitian

\subsection{Perencanaan.}

Kegiatan yang dilakukan dalam tahap perencanaan meliputi:a).menemukan masalah penelitian,dapat dilakukan melalui pengamatan langsung, b).merencanakan pemecahan masalah berupa langkah-langkah yang perlu dilakukan untuk mengatasi masalah yang dihadapi,c).menentukan kelas subjek penelitian,d).mendiskusikan strategi pembelajaran yang akan digunakan,e).menentukan aspek-aspek yang perlu di amati,f).menetapkan jenis data dan cara mengumpulkannya,g)menentukan kriteria keberhasilan siswa dalam uapaya mengatasi masalah yang ada. Bila pada tindakan pertama belum didapat hasil sesuai dengan indikator keberhasilan penelitian,maka penelitian dapat dilanjutkan pada tindakan kedua (tahap 2)

\subsection{Pelaksanaan tindakan.}

Kegiatan pada tahap ini adalah menggunakan TTS sebagai media pembelajaran.Media TTS yang digunakan sesuai pembelajaran klasifikasi materi di SMP di kelas VII.

\subsection{Pengamatan}

Pada tahap ini dilaksanakan pengamatan terhadap proses pelaksanaan tindakan,akibat dan hasil tindakan.Pengamatan juga dilakukan terhadap seberapa jauh keberhasilan tindakan yang dilakukan untuk mencapai tujuan yang telah direncanakan. 


\subsection{Refleksi}

Hasil yang didapat dalam tahap pengamatan,dikumpulkan dan dianalisis.Berdasarkan data hasil pengamatan,dapat diketahui apakah proses pembelajaran dengan media TTS dapat meningkatkan prestasi belajar dan kreativitas siswa pada materi klasifikasi materi

\subsection{Lokasi dan subjek penelitian}

Penelitian tindakan ini di lakukan di SMP Negeri 3 Kecamatan Sunggal,Kabupaten Deli Serdang.Peneliti menetapkan SMP Negeri 3 Kecamatan Sunggal sebagai lokasi penelitian,karena peneliti sebagai pengajar di sekolah tersebut ingin memperbaiki kualitas pembelajaran.Subjek penelitian adalah siswa-siswi kelas VII-6 SMP Negeri 3 Sunggal semester ganjil tahun pelajaran 2016-2017.Jumlah siswa terdiri 17 orang siswa perempuan dan 17 orang siswalaki-laki.

\subsection{Teknik pengumpulan data}

Teknik pengumpulan data dalam penelitian ini mengacu pada pedoman yang dikeluarkan oleh Depdiknas (1999) yaitu :a)pedoman penelitian, b)catatan lapangan. Dengan demikian pengumpulan data secara kualitatif adalah 1)Pengamatan.Pengamatan dilakukan dengan mengamati fakta yang terjadi di lapangan selama pembelajaran berlangsung, yang meliputi cara Guru menerapkan TTS dalam pembelajaran klasifikasi materi .2)catatan lapangan.Catatan lapangan dalam penelitian ini berisikan tentang apa yang dilihat,didengar,dialami,dan dipikirkan peneliti selama pengumpulan data dengan bantuan lembar observasi.

\subsection{Indikator keberhasilan}

Indikator keberhasilan dalam penelitian tindakan ini adalah a).bertambahnya perbendaharaan kata,terutama istilah asing yang selama ini menjadi penghambat proses belajar mengajar.b).semakin mahir dan lancar dalam menggunakan kata-kata dan istilah asing secara tepat.c).dapat memformulasikan bahasa secara baik dan benar untuk menjabarkan suatu ide atau konsep.Indikator ini tertuang pada hasil belajar siswa yaitu siswa dinyatakan lulus bila telah menguasai minimal 70\% materi yang di berikan (sesuai kriteria ketuntasan minimal/KKM),sedangkan target penelitian yaitu bila $70 \%$ siswa telah mencapai KKM pada pembelajaran klasifikasi materi,untuk indikator penilaian kreativitas yaitu bila siswa memiliki keberanian menyatakan pendapat,percaya diri,menghargai pendapat orang lain,bekerja sama dan teliti [3].

\section{Hasil dan Pembahasan}

\subsection{Hasil}

\subsubsection{Tahap Pertama}

Siklus Perencanaan. Berdasarkan hasil pengamatan yang telah dilaksanakan dari permasalahanyang dihadapi terlihat bahwa:a)walaupun siswa aktif dalam kegiatan pembelajaran, tetapi siswa tidak memahami materi karena tidak paham dengan istilah-istilah asing,b)siswa kurang kreativitas dan tidak berani menyatakan pendapat,hal ini dapat diamati pada saat guru mengajukan pertanyaan siswa malu-malu menjawab karena takut salah dan ditertawakan temannya.Berdasarkan permasalahan tersebut peneliti ingin mengatasi permasalahan dengan a)memanfaatkan teka teki silang untuk meningkatkan prestasi belajar siswa pada pembelajaran klasifikasi materi. b)Menumbuhkan kreativitas dan semangat belajar siswa untuk lebih responsif dalam pembelajaran.Pelaksanaan tindakan penelitian di rencanakan atas 3 bagian :1)kegiatan awal yang meliputi kegiatan membentuk persepsi dan motivasi.2)Kegiatan inti merupakan pelaksanaan kegiatan pembelajaran yang sesungguhnya,dimana Guru melaksanakan rancangan strategi pembelajaran yang telah di buat kepada siswa.3)Kegiatan akhir yang merupakan kegiatan penutup yang meliputi kegiatan menyimpulkan materi pembelajaran dan pemberian post test [4]. 
Siklus pelaksanaan Tindakan. Sebelum rancangan pembelajaran dilaksanakn,terlebih dahulu di lakukan pre tes .tujuan pelaksanaan pre tes adalah untuk melihat sejauh mana tingkat pemahamanyang dimiliki siswa sebelum di lakukan uji tindakan.Pre Tes di lakukan pada tanggal 19 agustus 2016 yang meliputi :

Kegiatan awal (10 menit). Proses kegiatan dimulai dengan kegiatan membentuk kelompok. Siswa di kelompokkan menjadi 7 kelompok, tiap kelompok beranggota 4-5 orang siswa.Guru memotivasisiswa dengan pertanyaan "apakah oksigen termasuk materi?apakah lambang untuk oksigen?".Guru menyampaikantujuan pembelajaran yang hendak dicapai.

Kegiatan inti (50 menit). Pada kegiatan inti, siswa berdiskusi tentang klasifikasi materi yang banyak terdapat istilah-istilah asing, agar siswa terbiasamendengar dan melihat istilah-istilah asing. Siswa diminta menyebutkan nama unsur dan lambangnya secara bergiliran.Peneliti kemudian menyajikan teka teki silang melalui in focusdanbertindak sebagai moderator. Peneliti mengajukan berbagai pertanyaanyangdijawab siswa dengan antusias.

kegiatan penutup (20 menit). Siswa dengan bantuan Guru menyimpulkan hasil pembelajaran, dilanjutkan dengan pemberian test.Tujuan pemberian post test ini untuk mengetahui sejauhmana pemahaman siswa terhadap materi yang diajarkan.

Siklus pengamatan. Selama berlangsung siklus pertama,peneliti mengamati proses pelaksanaan tindakan.Pengamatan di batasi pada fokus penelitian yang meliputi penggunaan TTS untuk memudahkan siswa mempelajari materi,serta mengembangkan kreativitas siswa dalam pembelajaran [5]. Hasil catatan lapangan prestasi dan kreativitas tahap 1 dapat dilihat pada "Tabel 1"

$\begin{array}{ll}\text { Pelaksanaan } & \text { : kelas VII-6 } \\ \text { Pengamatan } & \text { : Jum'at 19agustus } 2017 \\ \text { Pukul } & : 7.50 \text { wib-09.10 wib. }\end{array}$

Tujuan

Pelaksanaannya

: Menggunakan media TTS untuk meningkatkan prestasi belajar siswa pada pembelajaran klasifikasi materi.

:Guru telah menyiapkan note book dan infocus yang berisi TTS.Kemudian siswa di bagi menjadi 7 kelompok dengan anggota kelompok 4-5 orang.Guru memotivasi siswa untuk mempelajari tentang klasifikasi materi selama 15 menit dan menggaris bawahi istilahistilah asing yang sulit dimengerti siswa.Kemudian tiap kelompok berusaha menyelesaikan TTS yang di buat Guru.Kelompok yang pertama sekali dapat menyelesaikan di beri nilai 100 .

Tabel 1.Observasi Prestasi Dan Kreativitas Tahap 1

\begin{tabular}{|c|c|c|c|c|}
\hline No & Aspek yang di amati & $\begin{array}{l}\text { Hasil } \\
\text { Analisi } \\
\mathrm{s}\end{array}$ & Deskriptor & Catatan pengamat \\
\hline 1 & $\begin{array}{l}\text { Kreativitas siswa dalam menggunakan TTS: } \\
\text { a.keberanian menyatakan pendapat } \\
\text { b.percaya diri } \\
\text { c.menghargai pendapat orang lain } \\
\text { d.bekerja sama } \\
\text { e.Berani mengambil resiko }\end{array}$ & $\begin{array}{l}\text { BT } \\
\text { MT } \\
\text { MT } \\
\text { MB } \\
\text { MB }\end{array}$ & $\begin{array}{l}\text { BT=Belum Terlihat (apabila siswa belum } \\
\text { memperlihatkan tanda-tanda awal perilaku/karakter } \\
\text { yang dinyatakan dalam indikator,skor 1) } \\
\text { MT=Mulai Terlihat (apabila siswa sudah mulai } \\
\text { memperlihatkan tanda- } \\
\text { tanda awal perilaku/karakter yang dinyatakan } \\
\text { dalam indikator tetapi belum konsisten,skor 2) } \\
\text { MB: Mulai Berkembang (apabila siswa sudah } \\
\text { memperlihatkan berbagai tanda perilaku/karakter } \\
\text { yang dinyatakan dalam indikator dan mulai } \\
\text { konsisten,skor 3) }\end{array}$ & $\begin{array}{l}\text { Hanya } 22 \text { 0rang } \\
\text { yang berani } \\
\text { berpartisipasi }\end{array}$ \\
\hline
\end{tabular}




\begin{tabular}{|c|c|c|c|c|}
\hline & & & $\begin{array}{l}\text { MK: Membudaya (apabila siswa terus menerus } \\
\text { memperlihatkan perilaku/karakter yang dinyatakan } \\
\text { dalam indikator secara konsisten,skor 4). }\end{array}$ & \\
\hline \multirow[t]{6}{*}{2} & \multirow{2}{*}{\multicolumn{2}{|c|}{$\begin{array}{l}\text { Pemahaman siswa dalam pembelajaran } \\
\text { meliputi : }\end{array}$}} & B=Baik (apabila mencapai skor 85-100) & Hanya 20 orang \\
\hline & & & $\mathrm{C}=$ Cukup (apabila mencapai skor 70-84) & yang mengikuti \\
\hline & a.Bertambahnya perbendaharaan kata & B & $\mathrm{K}=$ Kurang(apabila mencapai skor $<70)$ & Pembelajaran \\
\hline & b.mahir menggunakan istilah asing & B & & dengan antusias \\
\hline & c.Memformulasikan bahasa secara tepat & $\mathrm{K}$ & & \\
\hline & & $\mathbf{K}$ & & $\begin{array}{l}\text { Keterkaitan TTS } \\
\text { dengan materi }\end{array}$ \\
\hline \multirow[t]{3}{*}{3} & Penggunaan Teka teki silang & & & pembelajaran \\
\hline & a.Keterkaitan kata-kata kunci dengan materi & B & & telah membentuk \\
\hline & b.membentuk motivasi siswa & B & & $\begin{array}{l}\text { persepsi dan } \\
\text { motivasi siswa }\end{array}$ \\
\hline
\end{tabular}

Tanggapan Pengamat : Saat pembelajaran di laksanakan,siswa belum dapat beradaptasi dengan metode yang di gunakan Guru

Siklus Refleksi. Pada tahap pertama pembelajaran dengan media TTS, ada beberapa kendala yang dihadapi berupa :1)ketersediaan waktu, siswa kurang waktu dalam membaca bahan pembelajaran,sehingga masih ada siswa yang kesulitan memahami istilah-istilah asing dalam proses belajarnya.2)masih ada siswa yang tidak berani berpendapat sehingga menghambat kreativitas dan keaktifan siswa tersebut.Setelah diberikan post test pada akhir pembelajaran,siswa yang berhasil mendapatkan skor diatas 60 berjumlah 22 orang ( $61 \%$ ) dengan hasil pengamatan hanya 20 orang siswa $(60 \%)$ berani menyampaikan pendapat.Karena hasil penelitian belum memcapai target 70 $\%$,maka di lanjutkan pada tahap kedua.

\subsubsection{Tahap Kedua}

Siklus Perencanaan. Siklus ini dilakukan pada tanggal 22 agustus 2016 dengan subpokok bahasan sifat-sifat unsur.Berdasarkan refleksi pada tahap pertama langkah-langkah tindakan pada tahap kedua merupakan perbaikan dari tahap pertama yaitu :1)memberikan waktu yang lebih lama pada siswa untuk membaca materi yang diberikan,2)meyakinkan siswa untuk menjawab pertanyaan yang diberikan dengan percaya pada kemampuan diri sendiri.

Siklus Pelaksanaan tindakan. Adapun siklus pelaksanaan tindakan diuraikan sebagai berikut :a)kegiatan awal (10 menit)dilakukan dengan memberikan persepsi dan motivasi dengan pertanyaan "Apa yang akan terjadi bila di bumi tidak terdapat oksigen?".Guru memberitahukan tujuan yang akan dicapai pada pembelajaran ini.Siswa dibagi menjadi 7 kelompok untuk mendiskusikan tentang sifat-sifat unsur kimia.b)Kegiatan inti (50 menit).Tindakan ini bertujuan untuk memudahkan siswa memahami materi sifat-sifat unsur kimia.Peneliti lebih memfokuskan pada kegitan siswa menemukan istilah-istilah asing yang sulit di pahami pada materi pembelajaran.Guru menyajikan teka teki silang,agar siswa lebih termotivasi,siswa dirangsang untuk mengajukan jawaban sebanyak-banyaknya,walaupun banyak kemungkinan salah,hal ini untuk membiasakan siswa mempelajari dan mengucapkan istilah-istilah asing.c)Kegiatan penutup ( 20 menit) dilakukan dengan menarik kesimpulan pembelajaran dan pemberian post test.

Siklus Pengamatan. Berdasarkan data di lapangan dan hasil pengamatan menunjukkan bahwa 29 0rang siswa (85\%) memiliki keberanian menyatakan pendapat, percaya diri, menghargai pendapat orang lain,bekerja sama dan berani mengambil resiko dari keputusan yang telah ditetapkan. Sedangkan hasil jawaban post test pada tahap kedua menunjukkan bahwa sebanyak 26 orang siswa $(75 \%)$ memperoleh nilai di atas 70 . Hasil observasi tahap 2 dapat dilihat pada "Tabel 2".

$\begin{array}{ll}\text { Catatan lapangan } & \text { : Tahap 2 } \\ \text { Pelaksanaan } & \text { : kelas VII-6 } \\ \text { Pengamatan } & \text { : Senin,22 agustus 2017. } \\ \text { Pukul } & : \text { : } 99.50 \text { wib-11.10 wib }\end{array}$


Tujuan

Pelaksanaannya

: Menggunakan media TTS untuk meningkatkan prestasi dan kreativitas ssiswa pada materi sifat-sifat unsur.

: Seperti pada pertemuan sebelumnya,Guru menyiapkan in focus yang berisi teka teki silang.Siswa di bagi menjadi 7 kelompok dan setiap kelompok beranggotakan 4-5 orang.Guru memberi kesempatan pada siswa untuk mempelajari materi sistem indera pada manusia selama 30 menit.Kemudian tiap kelompok berusaha menyelesaikan TTS yang di buat Guru.Kelompok yang pertama sekali dapat menyelesaikan di beri nilai 100 .

Tabel 2.Observasi Prestasi Dan Kreativitas Tahap 2

\begin{tabular}{|c|c|c|c|c|}
\hline No & Aspekyang di amati & $\begin{array}{l}\text { Hasil } \\
\text { Analisis }\end{array}$ & Deskriptor & $\begin{array}{l}\text { Catatan } \\
\text { pengamat }\end{array}$ \\
\hline 1 & $\begin{array}{l}\text { Kreativitas siswa dalam menggunakan TTS: } \\
\text { a.keberanian menyatakan pendapat } \\
\text { b.percaya diri } \\
\text { c.menghargai pendapat orang lain } \\
\text { d.bekerja sama } \\
\text { e.Berani mengambil resiko }\end{array}$ & $\begin{array}{l}\text { BT } \\
\text { MT } \\
\text { MT } \\
\text { MB } \\
\text { MB }\end{array}$ & $\begin{array}{l}\text { BT =Belum Terlihat (apabila siswa belum } \\
\text { memperlihatkan tanda-tanda awal perilaku/karakter } \\
\text { yang dinyatakan dalam indikator,skor 1) } \\
\text { MT=Mulai Terlihat (apabila siswa sudah mulai } \\
\text { memperlihatkan tanda- } \\
\text { tanda awal perilaku/karakter yang dinyatakan } \\
\text { dalam indikator tetapi belum konsisten,skor 2) } \\
\text { MB: Mulai Berkembang (apabila siswa sudah } \\
\text { memperlihatkan berbagai tanda perilaku/karakter } \\
\text { yang dinyatakan dalam indikator dan mulai } \\
\text { konsisten,skor 3) } \\
\text { MK: Membudaya (apabila siswa terus menerus } \\
\text { memperlihatkan perilaku/karakter yang dinyatakan } \\
\text { dalam indikator secara konsisten,skor 4). }\end{array}$ & $\begin{array}{l}29 \text { 0rang yang } \\
\text { berani } \\
\text { berpartisipasi }\end{array}$ \\
\hline 2 & $\begin{array}{l}\text { Pemahaman siswa dalam pembelajaran meliputi } \\
: \\
\text { a.Bertambahnya perbendaharaan kata } \\
\text { b.mahir menggunakan istilah asing } \\
\text { c.Memformulasikan bahasa secara tepat }\end{array}$ & $\begin{array}{l}\mathrm{B} \\
\mathrm{K}\end{array}$ & $\begin{array}{l}\text { B=Baik (apabila mencapai skor 85-100) } \\
C=\text { Cukup (apabila mencapai skor 70-84) } \\
\text { K=Kurang (apabila mencapai skor }<70)\end{array}$ & $\begin{array}{l}\text { Hanya } 26 \\
\text { orang yang } \\
\text { mengikuti } \\
\text { Pembelajaran } \\
\text { dengan } \\
\text { antusias }\end{array}$ \\
\hline 3 & $\begin{array}{l}\text { Penggunaan Teka teki silang } \\
\text { a.Keterkaitan kata-kata kunci dengan materi } \\
\text { b.membentuk motivasi siswa }\end{array}$ & $\begin{array}{l}\text { B } \\
\text { B }\end{array}$ & & $\begin{array}{l}\text { Keterkaitan } \\
\text { TTS dengan } \\
\text { materi } \\
\text { pembelajaran } \\
\text { telah } \\
\text { membentuk } \\
\text { persepsi dan } \\
\text { motivasi siswa }\end{array}$ \\
\hline
\end{tabular}

Tanggapan Pengamat :Saat pembelajaran di laksanakan,siswa telah dapat beradaptasi dengan metode yang di gunakan Guru

Siklus Refleksi. Pelaksanaan tindakan pada tahap kedua menunjukkan :a)meningkatnya prestasi dan kreativitas siswa terhadap materi pembelajaran.b)suasana pembelajaran yang lebih menyenangkan,lebih fokus dan antusias dalam mengikuti pembelajaran. Karena hasil pengamatan,catatan lapangan dan hasil post test siswa menunjukkan 75 $\%$ siswa mengalami kemajuan,maka penelitian tidak perlu di lanjutkan pada tahap berikutnya. 


\subsection{Pembahasan}

Penelitian tindakan kelas ini menunjukkan bahwa penggunaan media TTS (Crossword puzzle) dapat menciptakan suasana belajar yang lebih hidup dan menyenangkan sehingga pembelajaran menjadi lebih efektif.Pada penelitian juga di temukan bahwa media TTS dapat memotivasi siswa dalam pembelajaran.Sebagai permainan,TTS juga dapat digunakan sebagai media yang efektif untuk belajar mandiri.

Sebagai seorang guru yang memiliki tanggung jawab mendidik, maka Guru dituntut untuk mengembangkan potensi pada diri anak.Sehingga kegiatan mendidik tidak hanya terjadi di dalam kelas,tapi di manapun dan kapanpun.Melalui pembelajaran IPA, Guru dapat mendidik siswa untuk lebih memahami kehidupan dengan mengaitkan kejadian sehari-hari yang di alami siswa dengan materi yang ada pada kegiatan pembelajaran

\section{Kesimpulan}

Berdasarkan hasil dan pembahasan penelitian disimpulkan :

1. Media TTS dapat dijadikan sebagai salah satu media berbasis permainan yang dapat meningkatkan prestasi belajar siswa pada materi klasifikasi materi di kelas VII.

2. Media TTS dapat dimanfaatkan untuk meningkatkan kreativitas belajar siswa pada materi klasifikasi materi di kelas VIIdan membentuk prilaku positif pada diri siswa seperti percaya diri,berani mengemukakan pendapat,berani mengambil keputusan dan mau menghargai pendapat orang lain.

\section{Referensi}

[1] Luluk Fajri, Kus Sri Martini \&Agung Nugroho C.S.,2012.Upaya Peningkatan Proses Dan Hasil Belajar Kimia Materi Koloid Melalui Pembelajaran Kooperatif Tipe TGT(Teams Games Tournament) Dilengkapi Dengan Teka-Teki Silang Bagi Siswa Kelas Xi Ipa 4 Sma Negeri 2 Boyolali Pada Semester Genap Tahun Ajaran 2011/2012.Jurnal Pendidikan Kimia,I:89-96

[2] Fathonah R. S.,Sugiharto,\&Suryadi Budi Utomo,2013.Studi Komparasi Penggunaan Media Teka-Teki Silang (TTS) Dengan Kartu Padapembelajaran Kimiamelalui Pendekatan Contextual Teaching And Learning (Ctl) Terhadap Prestasi Belajar Siswa Pada Materi Zat Adiktif Dan Psikotropika Kelas Viii Smp N 2 Ngadirojo, Wonogiri Tahun Pelajaran 2011/2012.Jurnal Pendidikan Kimia,2:68-76

[3] Oemar Hamalik,(1985).Media Pendidikan.Alumni, Bandung. Peraturan Menteri Pendidikan Nasional No.41Tahun 2007.Tentang standarProses Untuk Satuan Pendidikan dasar dan Menengah.

[4] Nana Sudjana \& Ahmad,(1991).Media Pengajaran. Sinar Baru, Bandung.

[5] Pupuh fathurrahman \& M.sobry sutikno.(2007).Strategi Belajar Mengajar. Rafika Aditama,Bandung. 